\title{
On-line monitoring of mixed venous oxygen saturation after cardiothoracic surgery
}

\author{
X. HA N N KRAUSS, PIETER D. VER DOUW, \\ PAULG. HUGENHOLTZ, and JAN NAUTA
}

Thoraxcenter, University Hospital and Medical Faculty, Rotterdam, The Netherlands

\begin{abstract}
Krauss, X. H., Verdouw, P. D., Hugenholtz, P. G., and Nauta, J. (1975). Thorax, 30, 636-643. On-line monitoring of mixed venous exygen saturation after cardiothoracic surgery. On-line monitoring of $\mathrm{MVO}_{2}$ sat. in vivo by means of fibreoptic reflectometry was studied in 19 patients as to its predictive value during the postoperative course after thoracotomy for periods up to 60 hours. In all but one of the 10 patients with $\mathrm{MVO}_{2}$ sat. less than $65 \%$ for at least one hour complications occurred. A fall of $\mathrm{MVO}_{2}$ sat. of more than $5 \%$ or a value below $60 \%$ predicted a period of hypotension in six patients. In two of them this coincided with a period of ventricular arrhythmias. In those with $\mathrm{MVo}_{2}$ sat. greater than $65 \%$ no postoperative complications such as arrhythmias, shock, respiratory dysfunction or oliguria took place.

Since $\mathrm{MVO}_{2}$ sat. and cardiac index were shown to deviate in parallel $(\mathrm{r}=0.78$; $\mathrm{n}=28$ ) the former may be used as an indicator of the latter. Respiratory dysfunction could also immediately be detected by decreases in $\mathbf{M V o}_{2}$ sat. Turning a patient to his side at times caused a fall of $\mathrm{MVO}_{2}$ sat. of more than $10 \%$. Furthermore, $\mathrm{MVo}_{2}$ sat. reflected immediately beneficial or detrimental effects of blood transfusion or inotropic agents.

It is concluded that continually measured $\mathrm{MVo}_{2}$ sat. is a helpful adjunct in postoperative management. In fact it may be the best early warning indicator of the patient's course after cardiothoracic surgery, although extensive clinical experience needs to be collected before its definitive value will be known.
\end{abstract}

In the postoperative course of patients after thoracic surgery, the circulatory and/or respiratory systems are often impaired, particularly when confronted with augmented metabolic demands. Failure of these systems in turn leads to an increasing oxygen-deficit, which, according to the study of Crowel and Smith (1964), is the main determinant of survival in shock. Weil and Afifi (1970) come to the same conclusion in their study. Since mixed venous oxygen saturation $\left(\mathrm{MVo}_{2}\right.$ sat.) reflects the difference between the amount of oxygen offered and that consumed by the tissues, one might postulate that a low $\mathbf{M V o}$ sat. may be considered as an indicator of the increasing oxygen-deficit and thus of prognosis. Inasmuch as $\mathrm{MVO}_{2}$ sat. is related to oxygen consumption, cardiac output, and arterial oxygen content, as described in the classical equation by Fick, the value of $\mathbf{M V o}_{2}$ sat. as a predictor of cardiac output itself might once more be investi- gated now that continuous in vivo oxymetry has become available for use in the intensive care unit.

Previous authors Goldman et al., 1968; Scheinman, Brown, and Rapaport, 1969; Hutter and Moss, 1970) analysed $\mathrm{MVO}_{2}$ sat. in vitro from $\frac{7}{0}$ samples withdrawn from the right side of the heart and proved its prognostic significance. However, N the disadvantage of frequent and intermittent determinations of individual blood samples has precluded its wide acceptance in postoperative $\omega$ care. In previous reports from this and other laboratories (Krauss et al., 1972; Taylor, Lown, $\stackrel{O}{C}$ and Polanyi, 1972), the practical feasibility of $\Phi_{0}$ continual fibreoptic measurement of $\mathrm{MVO}_{2}$ sat. has been demonstrated. This method is based on sending alternating brief pulses of light of 660 and $805 \mathrm{~nm}$ wavelength through glass or plastic fibres, inserted in a catheter, to its tip located at 
a given site in the bloodstream. The reflected light is transmitted via a second set of fibres to a photoelectric device. As the ratio of the intensities of the backscattered light of the two wavelengths is a measure of oxygen saturation (or when 805 and $910 \mathrm{~nm}$ are employed of indocyanine green concentration), the system allows instantaneous and continuous assessment of $\mathrm{MVo}_{2}$ sat. as well as intermittent measurement of cardiac output without any need for withdrawal of blood.

The present report relates the experience in 19 patients of such continuous monitoring of $\mathrm{MVO}_{2}$ sat. and of intermittent determinations of cardiac outputs over periods of $20-60$ hours after surgery.

\section{METHODS AND MATERIAL}

THE CATHETER The fibreoptic catheters used in this study are triple lumen balloon Swan-Ganz (7 French) catheters. Approximately 150 glassfibres $^{1}(0.0025 \mathrm{~cm}$ diameter $)$ are present in the lumen that is also used for inflation of the balloon. One of the two conduits of the catheter ends at the tip (next to the fibre endings), the other at approximately $15 \mathrm{~cm}$ from the tip. The proximal lumen can be used for injection of cardiogreen. Its position is such that this side hole opening is positioned in the right atrium or ventricle when the fibreoptic tip is in the pulmonary artery. The catheter can be used to measure cardiac output, oxygen saturation, pulmonary capillary wedge pressure or pulmonary artery pressure and right atrial (or ventricular) pressure.

Calibration of the catheter for oxygen saturation and dye concentrations is carried out under non-sterile conditions. After this the catheter is sterilized and kept ready for use. This approach has the advantage that the procedure at the bed-side is strictly limited to the insertion of the flow-guided catheter. When oxygen saturation is measured the catheter can be further controlled in vivo by comparison with samples taken from the distal lumen.

THE REFLECTOMETER ${ }^{2}$ The instrument consists of two parts-an optical head and an electronic unit. The optical head contains light-emitting diodes producing the desired wavelengths, the light detector, and a bypass arrangement for calibration. The bypass arrangement allows a check for drift in the electronic unit to be performed at

${ }^{1}$ The catheters used at present contain plastic fibres 'American Optical Corporation, Framingham, Mass, USA any time during the monitored period. The use of diodes instead of conventional tungsten lamps with optical filters has reduced the size of the optical head considerably $(10 \times 5 \times 3 \mathrm{~cm})$. This allows attachment of the entire assembly to the upper arm of the patient, permitting him to move more freely in bed.

The electronic unit can be placed at a site remote from the patient's bed-side. It contains the power supply, calibration controls, filters for varying response times, a selector to determine the operation mode (oxygen saturation or indocyanine green concentration), a digital read-out of the measurement, and outlets for a direct writer and for computer processing of the signal.

In addition, a second meter is present to indicate the intensity of the reflected reference light. Since the latter is a measure of the performance of the catheter, it can be readily assessed whether the catheter is functioning normally or giving false readings. Excessive fibrin deposit on the tip of the catheter, lodging of the tip against the vessel wall or broken fibres can all be detected promptly.

PATIENT MONITORING The 19 patients undergoing heart (16) or lung (3) surgery were between 11 and 65 years of age. Diagnosis, operative procedure, and postoperative course are listed in Table I. In 12 patients the catheter was inserted the night before surgery. This permitted the measurement of preoperative control data. In the other patients the catheter was inserted after surgery. In these instances the tip of the catheter was left in the superior caval vein. Fluoroscopy was occasionally required to manipulate the catheter into the pulmonary artery. The analog signal from the haemoreflectometers was sent to a computer (Digital Equipments PDP-9) in order to record and store the mean oxygen saturation values over every minute of the recording period. The resultant data are displayed on the bedside television monitor together with other data such as heart rate, dispersion of the P-R intervals of the ECG, premature beats, arterial blood pressure, pulmonary artery pressure, and left atrial pressure. An extensive description of the computerized intensive care patient monitoring (ICPM) system employed at the University Hospital, Rotterdam has been given by Miller, Laird, and Hugenholtz (1971). In addition, off-line data were monitored, such as cardiac arrhythmias, cardiac index from dye-dilution curves, arterial blood samples for blood gases, and acid-base balance (Radiometer BMS-MK2). Ventilatory assistance was provided 
T A B L E I POSTOPERATIVE OBSERVATIONS IN 19 PATIENTS IN WHOM MIXED VENOUS OXYGEN

\begin{tabular}{|c|c|c|c|c|c|c|c|c|c|c|c|c|}
\hline \multirow{2}{*}{ No. } & \multirow{2}{*}{ Sex } & \multirow{2}{*}{ Age } & \multirow{2}{*}{$\begin{array}{c}\text { Diagnosis }^{1} \\
\text { Op. Procedure }\end{array}$} & \multirow{2}{*}{$(\mathrm{hr})$} & \multicolumn{2}{|c|}{$\mathrm{MVO}_{2}$ Sat. \% } & \multicolumn{2}{|c|}{ CI $\left(1 / \mathrm{min} / \mathrm{m}^{2}\right)^{2}$} & \multicolumn{2}{|c|}{ Art. Press. (mmHg) } & \multicolumn{2}{|c|}{$\mathrm{LAP}(\mathrm{mmHg})^{3}$} \\
\hline & & & & & Min & Max & Min & Max & Min & $\operatorname{Max}$ & Min & $\operatorname{Max}$ \\
\hline$\underset{1}{\text { Grout }}$ & $\stackrel{p}{A}$ & 40 & \multirow{10}{*}{$\begin{array}{l}\text { IHSS } \\
\text { Myotomy } \\
\text { CAD } \\
\text { SV bypass } \\
\text { Lung tumour } \\
\text { Lobectomy } \\
\text { VSD } \\
\text { Correction } \\
\text { Lung tumour } \\
\text { Lobectomy } \\
\text { AV Regurg. } \\
\text { Replacement } \\
\text { Subv. AS } \\
\text { Correction } \\
\text { Lung tumour } \\
\text { Lobectomy } \\
\text { ASD } \\
\text { Correction }\end{array}$} & \multirow{2}{*}{24} & 66 & 78 & \multirow[b]{2}{*}{$2 \cdot 7$} & \multirow[b]{2}{*}{$3 \cdot 1$} & $110 / 60$ & $180 / 90$ & \multirow[b]{2}{*}{$1 \cdot 2$} & \multirow[b]{2}{*}{4} \\
\hline 2 & $\mathbf{M}$ & 47 & & & 70 & 75 & & & $95 / 50$ & $145 / 80$ & & \\
\hline 3 & $\mathbf{M}$ & 62 & & 30 & 70 & 75 & $3 \cdot 1$ & $4 \cdot 4$ & $110 / 50$ & $155 / 65$ & 5 & \multirow[b]{4}{*}{13} \\
\hline 4 & $\mathbf{M}$ & 11 & & 20 & 67 & 76 & \multirow[b]{3}{*}{$2 \cdot 3$} & \multirow[b]{3}{*}{$4 \cdot 0$} & $100 / 60$ & $150 / 70$ & \multirow[b]{3}{*}{5} & \\
\hline 5 & $\mathbf{M}$ & 65 & & 26 & 74 & 80 & & & $120 / 60$ & $145 / 80$ & & \\
\hline 6 & $\mathbf{M}$ & 47 & & 28 & 68 & 73 & & & $105 / 60$ & $125 / 75$ & & \\
\hline 7 & $\mathrm{~F}$ & 34 & & \multirow{3}{*}{$\begin{array}{l}20 \\
24 \\
27\end{array}$} & 72 & 81 & & & $90 / 50$ & $105 / 60$ & 3 & 12 \\
\hline 8 & $\mathbf{M}$ & 65 & & & 74 & 78 & & & $110 / 80$ & $160 / 100$ & & \\
\hline 9 & $\mathrm{~F}$ & 27 & & & 76 & 84 & & & $115 / 60$ & $140 / 70$ & & \\
\hline \multicolumn{2}{|c|}{ Mean } & $44 \cdot 2$ & & $26 \cdot 1$ & $70 \cdot 8$ & $77 \cdot 8$ & $2 \cdot 7$ & $3 \cdot 8$ & $106 \cdot 1 / 58 \cdot 9$ & $145 / 76 \cdot 7$ & $3 \cdot 5$ & $10 \cdot 3$ \\
\hline Grout & $\begin{array}{l}p \\
\mathbf{M}\end{array}$ & 38 & \multirow{10}{*}{$\begin{array}{l}\text { AV Regurg. } \\
\text { Replacement } \\
\text { MS } \\
\text { Commissurotomy } \\
\text { CAD } \\
\text { SV bypass } \\
\text { V. Aneurysm } \\
\text { Resection } \\
\text { AS } \\
\text { Replacement } \\
\text { AV Regurg. } \\
\text { Replacement } \\
\text { V. Aneurysm } \\
\text { Resection } \\
\text { CAD } \\
\text { SV bypass } \\
\text { AV Regurg. } \\
\text { Replacement } \\
\text { MV Regurg. } \\
\text { Replacement }\end{array}$} & \multirow{2}{*}{48} & 58 & 63 & $2 \cdot 2$ & $3 \cdot 6$ & $100 / 60$ & $150 / 90$ & \multirow[t]{2}{*}{5} & \multirow[t]{2}{*}{12} \\
\hline 2 & $\mathrm{~F}$ & 42 & & & 60 & 74 & $1 \cdot 7$ & $2 \cdot 5$ & $105 / 55$ & $150 / 70$ & & \\
\hline 3 & $\mathbf{M}$ & 46 & & 60 & 58 & 70 & & & $80 / 45$ & $110 / 60$ & 13 & 20 \\
\hline 4 & $\mathbf{M}$ & 30 & & 28 & 62 & 70 & & & $100 / 55$ & $160 / 110$ & & \\
\hline 5 & $\mathrm{~F}$ & 48 & & 66 & 30 & 68 & & & $75 / 45$ & $140 / 75$ & 17 & 35 \\
\hline 6 & $\mathbf{M}$ & 53 & & 40 & 58 & 71 & $1 \cdot 8$ & $3 \cdot 4$ & $80 / 45$ & $105 / 60$ & 3 & 12 \\
\hline 7 & $\mathbf{M}$ & 45 & & 41 & 60 & 64 & $2 \cdot 0$ & $2 \cdot 8$ & $105 / 45$ & $140 / 30$ & 5 & 15 \\
\hline 8 & $\mathbf{M}$ & 42 & & 38 & 63 & 74 & $2 \cdot 5$ & $3 \cdot 3$ & $75 / 50$ & $115 / 70$ & 10 & 17 \\
\hline 9 & $\mathbf{M}$ & 50 & & 40 & 55 & 63 & & & $90 / 60$ & $120 / 80$ & 7 & 12 \\
\hline 10 & $\mathbf{M}$ & 22 & & 26 & 55 & 65 & $1 \cdot 55$ & $2 \cdot 6$ & $90 / 55$ & $110 / 80$ & 3 & 9 \\
\hline Mean & & $41 \cdot 6$ & & $41 \cdot 5$ & 55.9 & $68 \cdot 2$ & $2 \cdot 0$ & $2 \cdot 9$ & $89 \cdot 5 / 53$ & $130 / 77 \cdot 5$ & $7 \cdot 9$ & $16 \cdot 5$ \\
\hline
\end{tabular}

DEFINITIONS: Shock = mean art. press $<70 \mathrm{mmHg}$; Urine prod. $<20 \mathrm{ml} / \mathrm{hr}$; peripheral cyanosis and cold clammy skin

Renal failure = Urine prod. $<300 \mathrm{ml} / 24 \mathrm{hr}$ : serum creatinine $>4 \mathrm{mg} \%$.

${ }^{1} \mathrm{AS}, \mathrm{MS}=$ aortic, mitral stenosis; AV, MV = aortic, mitral valve; ASD = atrial septal defect; CAD = coronary artery disease; IHSS = 0 idiopathic hypertrophic subvalvular stenosis; $S V=$ saphenous vein; subv. AS $=$ subvalvular aortic stenosis; VSD = ventricular septal defect. ${ }^{2} \mathrm{CI}=$ cardiac index.

${ }^{3} \mathbf{L A P}=$ left atrial pressure.

${ }^{4} \mathrm{CVP}=$ central venous pressure.

SVA = ventricular arrhythmia.

$\mathrm{V}$. assist = ventilatory assistance.

${ }^{7}$ DIC = disseminated intravascular coagulation.

where necessary by Dräger Spiromat or a Bennett M-11 ventilator through a nasotracheal tube.

Twenty-four hours' urine production was measured in all patients, in 15 at hourly intervals.

\section{RESULTS}

GENERAL $\mathrm{MVO}_{2}$ was monitored continuously from 20 up to 60 hours (mean 37.5 ). The reliability of the method is demonstrated by comparison of the results of in vitro analysis of samples drawn through the same catheter with the simultaneous measurement by the fibreoptic system. A precau- tion which was taken was that the control readout did not change. This occurred more frequently o after the catheter had been left in situ for periods $N$ exceeding 36 hours. Often in these cases protein $N$ deposits on the catheter tip were observed after $\omega$ removal. While these deposits did not interfere with the measurements of oxygen saturation they ${ }_{C}$ prohibited the accurate measurement of cardiac $\stackrel{\oplus}{\Phi}$ output beyond 24 hours.

SEPaRATE Patient STUdies The results listed in $\frac{0}{\circ}$ Table I give patient data, type of operative pro- $\frac{\Omega}{\Phi}$ cedure, monitored period, and the range of the $\varrho$ 
SATURATION (MVo, SAT.) WAS MONITORED CONTINUOUSLY AFTER THORACIC SURGERY

\begin{tabular}{|c|c|c|c|c|c|c|c|c|c|c|c|}
\hline \multicolumn{2}{|c|}{$\mathrm{CVP}(\mathrm{mmHg})^{4}$} & \multirow{2}{*}{$\begin{array}{c}\text { Blood } \\
\text { Loss } \\
\text { (ml/24hr) }\end{array}$} & \multirow[t]{2}{*}{$\mathbf{V A}^{5}$} & \multicolumn{2}{|c|}{ Art. $\mathrm{O}_{2}$ Sat. $\%$} & \multirow{2}{*}{ V. Assist. } & \multicolumn{2}{|c|}{$\begin{array}{c}\text { Base Excess } \\
(\mathrm{mEq} / \mathrm{l})\end{array}$} & \multicolumn{2}{|c|}{ Urine $(\mathrm{ml} / \mathrm{hr})$} & \multirow[t]{2}{*}{ Remarks $^{?}$} \\
\hline Min. & Max. & & & Min. & Max. & & Min. & Max. & Min. & Max. & \\
\hline 4 & 14 & 580 & -- & 90 & 92 & --- & -1.9 & 0 & 10 & 60 & Atelectasis \\
\hline \multirow[t]{2}{*}{2} & 6 & 730 & -- & 97 & 98 & --- & -0.5 & $+0 \cdot 8$ & 30 & 120 & \\
\hline & & 800 & -- & 93 & & --- & - & & \multicolumn{2}{|c|}{$\overline{60}$} & \\
\hline 6 & 14 & 850 & -- & 93 & 96 & --- & -7 & -2 & \multicolumn{2}{|c|}{$\overline{50}$} & Haemorrhage \\
\hline $\mathbf{0}$ & 5 & 425 & -- & 97 & & --- & $-1 \cdot 4$ & & \multicolumn{2}{|c|}{$\overline{35}$} & \\
\hline 4 & 8 & 580 & -- & 94 & 96 & 17 & 0.8 & $2 \cdot 0$ & 20 & 70 & \\
\hline 2 & 7 & 650 & -- & 94 & 94 & 15 & -1 & -1 & 20 & 85 & \\
\hline 8 & 16 & 850 & -- & 91 & & --- & $-3 \cdot 0$ & $\mathbf{0}$ & \multicolumn{2}{|c|}{$\overline{35}$} & \\
\hline 0 & 4 & 550 & -- & 96 & 98 & --- & $-1 \cdot 8$ & 0 & 30 & 60 & \\
\hline $3 \cdot 3$ & $9 \cdot 3$ & $668 \cdot 3$ & & $94 \cdot 4$ & & & $-1 \cdot 5$ & & \multicolumn{2}{|c|}{$\overline{46 \cdot 9}$} & \\
\hline 4 & 7 & 930 & + & 92 & 96 & 15 & $-3 \cdot 3$ & -0.7 & 10 & 60 & \multirow{2}{*}{$\begin{array}{l}\text { Myocardial infarct } \\
\text { Isoprenaline }\end{array}$} \\
\hline 2 & 6 & 400 & - & 94 & 97 & --- & +0.3 & $+4 \cdot 0$ & 15 & 40 & \\
\hline 4 & 10 & 200 & $t+$ & 96 & 96 & 17 & -4 & +0.7 & 15 & 110 & \multirow{2}{*}{$\begin{array}{l}\text { Shock, late mortality } \\
\text { Lig. + Iso }\end{array}$} \\
\hline 2 & 6 & 630 & + & 92 & 94 & 26 & -6.5 & $-2 \cdot 2$ & 25 & 150 & \\
\hline 7 & 14 & 300 & ++ & 92 & 96 & 72 & $-5 \cdot 2$ & -5 & 4 & 40 & \multirow{7}{*}{$\begin{array}{l}\text { Shock, DIC, renal failure } \\
\text { Shock, DIC } \\
\text { Renal failure, late } \\
\text { mortality } \\
\text { Resp. distress } \\
\text { Lignocaine } \\
\text { Shock } \\
\text { Iso. + Lig } \\
\text { Shock, resp. distress } \\
\text { Lignocaine } \\
\text { Hypovolaemic shock }\end{array}$} \\
\hline 3 & 10 & 600 & + & 94 & 96 & 22 & -4 & -3 & 0 & 50 & \\
\hline 5 & 13 & 410 & ++ & 94 & 95 & 17 & $-2 \cdot 1$ & 0 & 10 & 55 & \\
\hline \multirow[t]{2}{*}{4} & 14 & 700 & ++ & 92 & 96 & 18 & $-5 \cdot 1$ & $+2 \cdot 8$ & 6 & 100 & \\
\hline & & 550 & ++ & 90 & 95 & 16 & $-1 \cdot 0$ & +0.7 & 10 & 60 & \\
\hline 1 & 8 & 650 & + & 94 & 98 & 16 & +0.9 & $+1 \cdot 2$ & 15 & 40 & \\
\hline $3 \cdot 6$ & $9 \cdot 7$ & 537 & & $93 \cdot 2$ & $95 \cdot 9$ & & $-3 \cdot 2$ & -2 & \multicolumn{2}{|c|}{$\overline{41 \cdot 5}$} & \\
\hline
\end{tabular}

following data: $\mathbf{M V o}_{\text {, sat., cardiac index, arterial }}$ blood pressure, left atrial and central venous pressure, blood loss, ventricular arrhythmias, arterial oxygen saturation, base excess or deficit, urine production and the period during which the patient was kept on a respirator. In the last column details on observed complications and therapy are given. The patients were divided into two groups; group A (nine patients), in which $\mathrm{MVo}_{2}$ sat. remained above $65 \%$; and group $\mathrm{B}$ (ten patients) in which it was under $65 \%$ for at least one hour of the monitored period. In group B there was only one patient (B2) who did not undergo open-heart surgery. Her $\mathbf{M V o}_{2}$ sat. remained well above $65 \%$ but dropped to $60 \%$ for about two hours, when she was turned on to her right side, which coincided with a fall of cardiac index from 2.5 to $1.71 /$ min per $\mathrm{m}^{2}$.

In nine patients cardiac index (CI) was determined intermittently. Its value ranged from $2 \cdot 3$ to $4.41 / \mathrm{min}$ per $\mathrm{m}^{2}$ in group $A$ and from 1.6 to $3.41 / \mathrm{min}$ per $\mathrm{m}^{2}$ in group B. A correlation was found between $\mathrm{CI}$ and $\mathrm{MVo}_{2}$ sat. $(r=0 \cdot 78 ; n=28$, $0.64<\mathrm{P}<0.92$ ), but only if the last parameter was stable for at least 5 minutes before and after the measurement of $\mathrm{CI}\left(\Delta \mathrm{MVO}_{2}\right.$ sat. $\left.<3 \mathrm{vol} \%\right)$. 
When the CI was less than $2.01 / \mathrm{min}$ per $\mathrm{m}^{2}$, MVo: sat. was below $60 \%$ in six out of eight patients. Also when CI was under $2.51 / \mathrm{min}$ per $\mathrm{m}^{2}$ all patients but one had a $\mathrm{MVo}_{2}$ sat. of less than $65 \%$. A strikingly parallel course of the two parameters was observed during the first 20 hours after surgery in patients A6, B1, B2, B6, and B10, especially when blood infusions or inotropic agents were administered.

Arterial blood pressure remained near normal in group $A$; in none of these patients were the clinical signs of shock, such as cold clammy skin, blood pressure under $90 / 60 \mathrm{mmHg}$ or urine production less than $20 \mathrm{ml} / \mathrm{min}$, seen. In contrast in group B, periods of low blood pressure together with these ominous signs were observed in six patients (B3, B5, B6, B8, B9, and B10). In each of these patients this was preceded by a fall of $\mathrm{MVO}_{2}$ sat. of more than $5 \%$ or to values less than $60 \%$. Simultaneously measured left atrial pressures indicated that the hypotension was related to hypovolaemia in three patients (B6, B9, B10) and to cardiac failure in the other three (B3, B6, B8). Left atrial pressures in group A were normal at levels below $15 \mathrm{mmHg}$ (Table I). In this group, blood loss was never severe except in patient A4, an 11-year-old boy, who lost $600 \mathrm{ml}$ in four hours. Serious ventricular arrhythmias, manifested by more than five premature ventricular beats per minute or by ventricular tachycardias, were not observed in group A. On the other hand, in group B such rhythm disturbances occurred in nine out of the 10 patients.
In four these required prolonged treatment with lignocaine (Table I). Arterial oxygen saturation differences between groups $A$ and $B$ were not $\bar{c}$ significant, perhaps because in the last group $\vec{\nabla}$ many more were kept on a respirator throughout the night after surgery. A period of respiratory $\mathrm{c}$ distress did occur in patients B7 and B9 after $\overrightarrow{0}$ extubation. This coincided with a serious fall of $\vec{A}$ $\mathrm{MVo}_{2}$ sat. in both patients. Base deficit in general $\tilde{\sigma}^{\circ}$ was much more severe in group B, despite several $\stackrel{2}{\rightleftharpoons}$ attempts at correction with $\mathrm{NaHCO}_{3}$ in the $\times$ operating theatre. In group A only patient A4 ${ }_{0}$ had a deficit of more than $3 \mathrm{mEq} / \mathrm{l}$. It is likely that in this patient serious haemorrhage was the cause. Although urine production of less than $20 \mathrm{ml} / \mathrm{hr}$ was frequently observed in group B, its significance could not be compared with group $A \vec{A}$ because many of the patients in the latter group $\mathbb{D}$

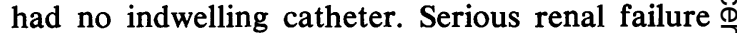
manifested by a serum creatinine above $4 \mathrm{mg} \%$ 응 and urine production below $300 \mathrm{ml} /$ day in com- $\stackrel{\Phi}{-}$ bination with disseminated intravascular coagula- $\vec{\theta}$ tion complicated the postoperative period of $v$ patients B5 and B6. It was treated by heparin and large doses of frusemide $(750-1000 \mathrm{mg}$ iv). Furthermore, it was evident that pressoramines and anti-arrhythmic drugs were much more frequently used in group B. Two patients (B3 $\stackrel{\circ}{\varnothing}$ and B6) died suddenly several weeks after dis- ำ charge from hospital. Another (B1) suffered a myocardial infarction during the operation as indicated by the postoperative electrocardiogram. Other aspects of therapy and of complications

T A B L E I I

DIFFERENCES IN POSTOPERATIVE COURSE OF PATIENTS IN GROUPS A AND B

\begin{tabular}{|c|c|c|}
\hline & Group A (9 patients) & Group B (10 patients) \\
\hline $\begin{array}{l}\text { Type of surgery } \\
\text { Monitored period } \\
\mathrm{MVO}_{2} \text { saturation } \\
\text { Cardiac index } \\
\text { Arterial pressure } \\
\text { Left atrial pressure } \\
\text { Blood loss } \\
\text { Serious ventricular arrhythmias } \\
\text { Arterial O2 sat. } \\
\text { Assisted ventilation } \\
\text { Base excess } \\
\text { Shock } \\
\text { Diss. intravascular coagulation } \\
\text { Renal failure } \\
\text { Late mortality }\end{array}$ & $\begin{array}{l}3 \text { lobectomies } \\
6 \text { intracardiac } \\
20-30 \mathrm{hr} \\
\text { range } 66-80 \% \\
\text { mean lowest value } 71 \% \\
\text { range } 2 \cdot 3-4 \cdot 41 / \mathrm{min}^{2} \mathrm{per} \mathrm{m}^{2} \\
\text { mean lowest value } \\
2 \cdot 71 / \mathrm{min} \text { per } \mathrm{m}^{2} \\
\text { range } 90 / 50-180 / 90 \mathrm{mmHg} \\
\text { mean lowest value } \\
106 / 59 \mathrm{mmHg} \\
1 \cdot 2-13 \mathrm{mmHg} \\
\text { abnormal }(>15):- \\
425-850 \mathrm{ml} / 24 \mathrm{hr} \\
90-98 \% \text { - } \\
2 \text { patients }- \\
\text { range }-3 \cdot 0-+2 \cdot 0 \mathrm{mEq} / 1 \\
\text { mean }-1 \cdot 5 \mathrm{mEq} / 1 \\
\quad-\end{array}$ & $\begin{array}{l}1 \text { commissurotomy } \\
9 \text { intracardiac } \\
22-60 \mathrm{hr} \\
\text { range } 30-70 \% \\
\text { mean lowest value } 56 \% \\
\text { range } 1 \cdot 55-3 \cdot 41 / \mathrm{min}^{2} \mathrm{per} \mathrm{m}^{2} \\
\text { mean lowest value } \\
2 \cdot 01 / \mathrm{min} \mathrm{per} \mathrm{m}^{2} \\
\text { range } 75 / 45-160 / 110 \mathrm{mmHg} \\
\text { mean lowest value } \\
90 / 53 \mathrm{mmHg} \\
3 \cdot 0-35 \mathrm{mmHg} \\
\text { abnormal: } 4 \mathrm{patients} \\
200-930 \mathrm{ml} / 24 \mathrm{hr} \\
9 \text { patients } \\
90-98 \% \\
9 \text { patients }(15-72 \mathrm{hr}) \\
\text { range }-6 \cdot 5-+4 \cdot 0 \mathrm{mEq} / 1 \\
\text { mean }-3 \cdot 2 \mathrm{mEq} / 1 \\
6 \text { patients } \\
2 \text { patients } \\
2 \text { patients } \\
2 \text { patients }\end{array}$ \\
\hline
\end{tabular}

Group A: $\mathrm{MVo}_{2}$ sat. above $65 \%$. Group B: $\mathrm{MVo}_{2}$ sat. below $65 \%$ for at least one full hour during monitored period. 
are given in the last column of Table I. A summary of the differences in the postoperative course of the two patient groups is given in Table II.

\section{DISCUSSION}

Kirklin and Rastelli (1967) found that complications, serious morbidity or death after intracardiac surgery are most often related to low cardiac output, to pulmonary dysfunction or to both. The same holds true for lung surgery although here the emphasis is more often on respiratory failure. It is therefore not surprising that the need to measure cardiac output regularly after thoracic surgery is generally felt. Unfortunately the measurement procedure remains technically complex so that the determination is not often carried out. In the present study attention was therefore focused on the value of $\mathrm{MVO}_{2}$ sat. as an indicator of the patient's condition and of his prognosis.

Our results showed that $\mathrm{CI}$ and $\mathrm{MVo}_{2}$ sat. correlated better than expected when these determinations were carried out during periods of 'steady' $\mathrm{MVO}_{2}$ sat. (no change over at least 5 minutes). Thus while no linear correlation exists, $\mathrm{MVO}_{2}$ sat. does indicate whether or not $\mathrm{CI}$ is within normal limits. This is further borne out by the parallel course of these parameters in our patients during the postoperative period. The conclusion is therefore reached that for clinical purposes $\mathrm{MVO}_{2}$ sat. provides a reliable first approximation of cardiac output and furthermore that its determinations should reduce the frequency with which the latter needs to be measured. These findings are somewhat in disagreement with those of Kirklin and Theye (1963), who did not find an acceptable correlation between the two parameters. This discrepancy may be explained by the fact that in the present study measurements were made in close succession by the same system only during the first 20 hours after operation.

Other factors are that during this period arterial oxygen saturation showed very little variation and that a period of 'steady' $\mathbf{M V o}_{2}$ sat. was awaited, because this parameter varies much more rapidly than was expected from the intermittent blood-sample analysis described in Kirklin and Theye's study. Furthermore, these authors sampled from the right atrium rather than the pulmonary artery, so that incomplete mixing may have been a factor. This same observation was made by Taylor et al. (1972). The findings of Raison et al. (1970) that total oxygen consump- tion remains unexpectedly steady, particularly in seriously ill patients, provided no shivering takes place, further strengthens the conclusion that $\mathrm{MVO}_{2}$ sat. may be utilized at least as an indicator of the level of cardiac output. The parallel course of $\mathrm{MVO}_{2}$ sat. and CI was again observed in patient B2, whose $\mathrm{MVo}_{2}$ sat. fell under $65 \%$ only for the two hours she was lying on her right side. The same observation was made pre- and postoperatively in patients B3 and B8; when turned on to their left sides a similar degree of diminution of $\mathrm{MVO}_{2}$ sat. and $\mathrm{CI}$ was seen.

Retrospective analysis of the 24-hour computer reports has shown that such variations in body position frequently lead to consistent changes in $\mathrm{MVO}_{2}$ sat. That this may be followed by serious complications was observed in patient B8, in whom a similar fall of $\mathrm{MVO}^{2}$ sat. preceded a period of ventricular arrhythmias, even ventricular tachycardia.

These arrhythmias were never observed in group A $\left(\mathrm{MVO}_{2}\right.$ sat. always $\left.>65 \%\right)$ whereas they occurred in nine out of 10 patients of group B. In two patients this complication was preceded by a fall of $\mathrm{MVO}_{2}$ sat. of more than $5 \%$ or under $60 \%$. Similar observations were made regarding periods of hypotension and shock, which were preceded by such declines of $\mathrm{MVO}_{2}$ sat. in six patients of group $B$. The beneficial and detrimental effects of blood transfusions or inotropic agents on the circulation are also reflected immediately by $\mathrm{MVO}_{2}$ sat., as observed in many of these patients.

$\mathrm{MVO}_{2}$ sat. is also an indicator of the functional adequacy of the respiratory system. This is demonstrated by the data given in Figure 1. In this computer-generated plot of $\mathrm{MVo}_{2}$ it is shown that suctioning of an endotracheal tube can drastically

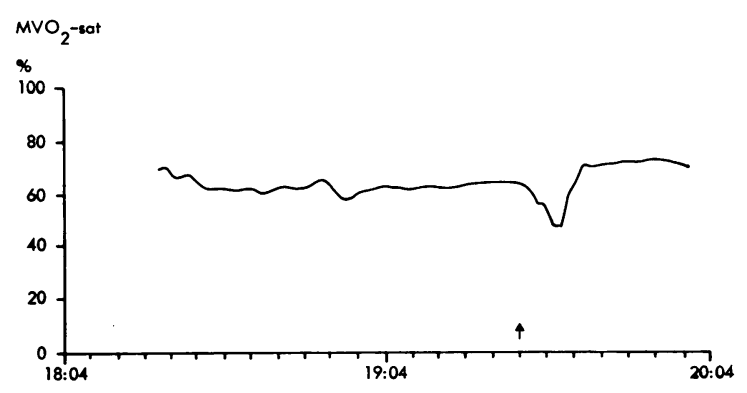

FIG. 1. Computer record (18.04-20.04 hours) of $\mathrm{MVO}_{2}$ sat. in patient $\mathrm{B} 8$, showing the effect of suctioning and cleaning of the endotracheal tube (started at arrow). 
lower $\mathrm{MVo}_{2}$ sat. While Hempelmann et al. (1972) have proven that tracheal suctioning can be a cause of severe arterial hypoxaemia, $\mathrm{MVo}_{2}$ sat. appears to be a readily available guide during such interventions. In the same way, pulmonary complications after extubation of patients, the influence of physiotherapy, and the beneficial effect of increasing the inspired oxygen content are reflected by $\mathrm{MVo}_{2}$ sat.

In general, these results of $\mathrm{MVO}_{2}$ sat. monitoring, summarized in Table II, show that serious complications were observed much less frequently when $\mathrm{MVo}_{2}$ sat. remained above $65 \%$ than when it fell below this value. This was particularly associated with periods of shock, ventricularo arrhythmias, respiratory distress, and oliguria. Ito appears as if $\mathrm{MVO}_{2}$ sat. below $65 \%$ reflects either $\frac{\bar{c}}{9}$ low cardiac output, respiratory dysfunction or combined cardiorespiratory failure, especiallyo when augmented metabolic demands might induces an intolerable oxygen deficit.

In conclusion and by way of illustration of $-\vec{\omega}$ several of these observations, the postoperativeo course of patient B5, a woman with aortic and mitral valve disease, is given (Fig. 2). As the mitral valve lesion did not seem to have haemodynamic importance at the time of surgery, onlyo the aortic valve was replaced. Within 12 hours.

\section{$48 \mathrm{jr}$. AORTIC VALVE and MITRAL VALVE REPLACEMENT}
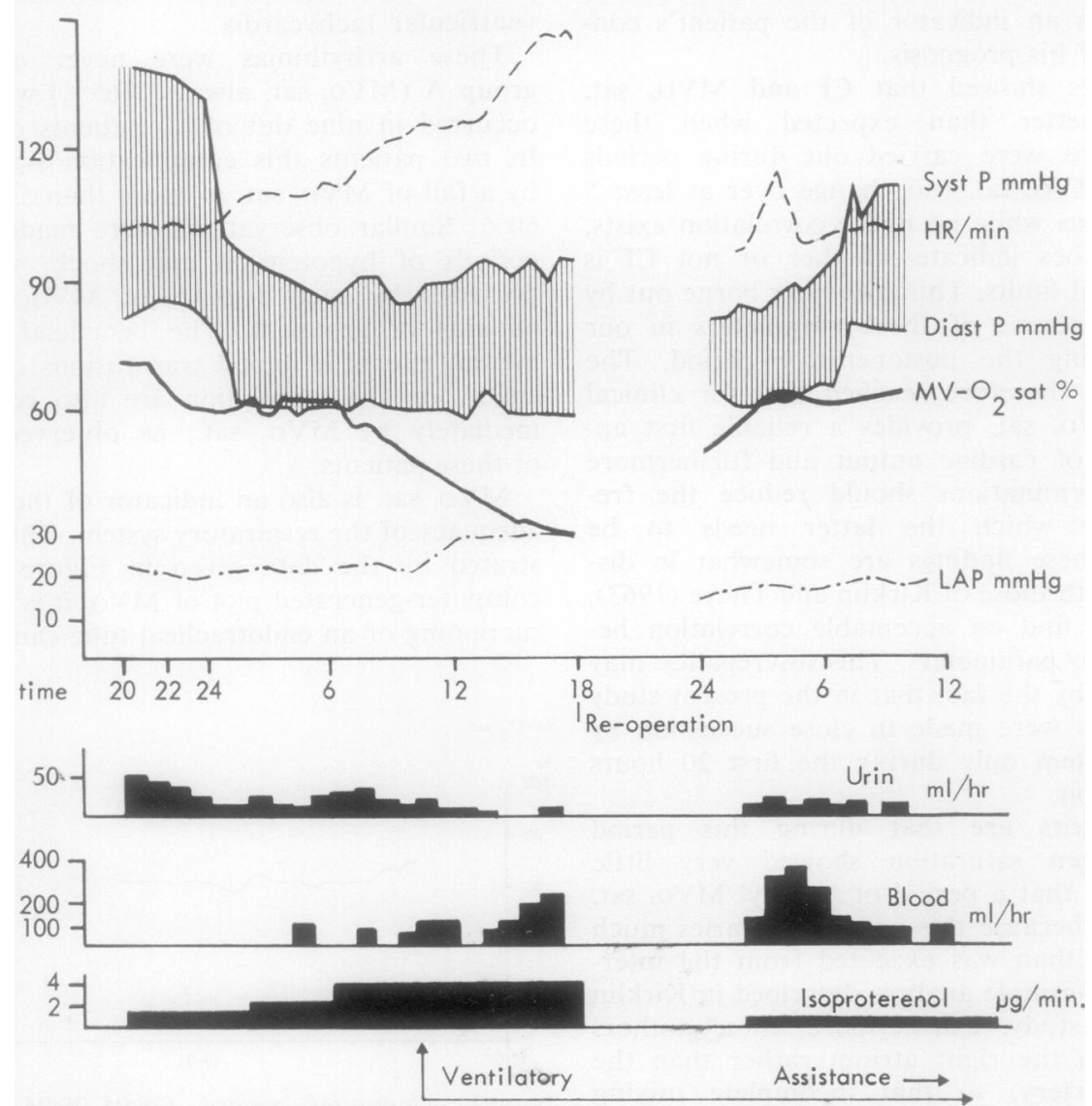

FIG. 2. Postoperative course of patient B5. Details are given in text. (Syst. $P=$ systolic pressure; Diast. $P=$ diastolic pressure; $H R=$ heart rate; $L A P=$ left atrial pressure.) 
after surgery she went into a profound shock state, which could not be reversed. She was therefore brought back to the operating room, where a severe mitral regurgitation was found. Although the mitral valve was replaced she remained initially in a critical condition, until further blood transfusions led to general improvement. As shown in Fig. 2, $\mathrm{MVo}_{2}$ sat. changes preceded both deterioration as well as improvement of her condition. If its course had been heeded more promptly a less extreme state of hypotension might have occurred.

\section{REFERENCES}

Crowel, J. W. and Smith, E. E. (1964). Oxygen deficit and irreversible hemorrhagic shock. American Journal of Physiology, 206, 313.

Goldman, R. H., Klunghaupt, M., Metcalf, T., Spivack, A. P., and Harrison, D. C. (1968). Measurement of central venous oxygen saturation in patients with myocardial infarction. Circulation, 38, 941.

Hempelmann, G., Karliczek, G., Helms, U., and Hempelmann, W. (1972). Akute hämodynamische Veränderung durch tracheobronchiales Absaugen. Zeitschrift für Kreislaufforschung, 61, 545.

Hutter, A. M. and Moss, A. J. (1970). Central venous oxygen saturations: value of serial determinations in patients with acute myocardial infarction. Journal of the American Medical Association, 212, 299.
Kirklin, J. W. and Rastelli, G. C. (1967). Low cardiac output after open intracardiac operations. Progress in Cardiovascular Diseases, 10, 117.

_ and Theye, R. A. (1963). Cardiac performance after open intracardiac surgery. Circulation, 28, 1061.

Krauss, X. H., Verdouw, P. D., Hugenholtz, P. G., Hagemeijer, F., and Polanyi, M. L. (1972). Continuous monitoring of $\mathrm{O}_{2}$ saturation in the intensive care unit (abstr.) Circulation, 45 and 46, Suppl. 2, 178.

Miller, A. C., Laird, J. D., and Hugenholtz, P. G. (1971). Computer science in the intensive care unit. Proceedings of the 3rd International Conference, Engineering Foundation, Davos, Switzerland.

Raison, J. C. A., Osborn, J. J., Beaumont, J. O., and Gerbode, F. (1970). Oxygen consumption after open heart surgery measured by a digital computer system. Annals of Surgery, 171, 471.

Scheinman, M. M., Brown, M. A., and Rapaport E. (1969). Critical assessment of use of central venous oxygen saturation as a mirror of mixed venous oxygen in severely ill cardiac patients. Circulation, 40, 165.

Taylor, J. B., Lown, B., and Polanyi, M. (1972). In vivo monitoring with a fiber optic catheter. Journal of the American Medical Association, $221,667$.

Weil, M. H. and Afifi, A. A. (1970). Experimental and clinical studies on lactate and pyruvate as indicators of the severity of acute circulatory failure (shock). Circulation, 41, 989.

Requests for reprints to: Dr. X. H. Krauss, Thoraxcenter, University Hospital, Rotterdam, The Netherlands. 